\title{
Novel Fatty Acid in Cordyceps Suppresses Influenza A (H1N1) Virus- Induced Proinflammatory Response Through Regulating Innate Signaling Pathways
}

Run-Feng Li, ${ }^{\text {II }}$ Xiao-Bo Zhou, ${ }^{\text {II }}$ Hong-Xia Zhou, ${ }^{\text {II }}$ Zi-Feng Yang, Hai-Ming Jiang, Xiao Wu, Wen-Jia Li, Jian-Jian Qiu, Jia-Ning Mi, Ming Chen, Nan-Shan Zhong, Guo-Yuan Zhu,* and Zhi-Hong Jiang*

Cite This: ACS Omega 2021, 6, 1505-1515

Read Online

ABSTRACT: Influenza virus (IV) infections usually cause acute lung injury characterized by exaggerated proinflammatory responses. The paucity of therapeutic strategies that target host immune response to attenuate lung injury poses a substantial challenge in management of IV infections. In this study, we chemically synthesized a novel fatty acid $(2 Z, 4 E)$-deca-2,4-dienoic acid (DDEA) identified from Chinese Cordyceps by using UHPLC-Q-TOF-MS techniques. The DDEA did not inhibit $\mathrm{H} 1 \mathrm{~N} 1$ virus replication but attenuated proinflammatory responses by reducing mRNA and protein levels of TNF- $\alpha$, IFN- $\alpha$, IFN- $\beta$, IL-6, CXCL-8/IL-8, CCL-2/MCP-1, CXCL-10/IP-10, CCL-3/ MIP- $1 \alpha$, and CCL-4/MIP-1 $\beta$ in A549 cells and U937-derived

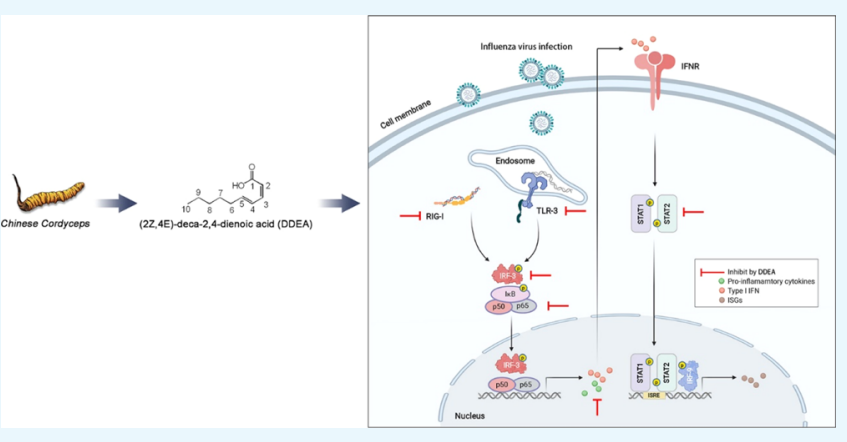
macrophages. The anti-inflammatory effect occurred through downregulations of TLR-3-, RIG-I-, and type I IFN-activated innate immune signaling pathways. Altogether, our results indicate that DDEA may potentially be used as an anti-inflammatory therapy for the treatment of IV infections.

\section{INTRODUCTION}

Influenza virus (IV) is a segmented negative-sense singlestranded RNA virus that represents a great burden on public health. The most common circulating subtypes are influenza $\mathrm{A}$ (H1N1) and $A(\mathrm{H} 3 \mathrm{~N} 2)$ viruses that cause seasonal epidemic with 250,000 to 500,000 deaths annually. ${ }^{1}$ Because of the ability to undergo adaptation, zoonotic influenza viruses such as avian influenza $\mathrm{H} 5 \mathrm{~N} 1$ and $\mathrm{H} 7 \mathrm{~N} 9$ viruses can occasionally cross the species barrier from poultry to humans, causing more severe disease than seasonal IVs. ${ }^{2,3}$ The burden of IV infection requires the use of antiviral medications to reduce viral shedding and relieve symptoms. At present, two classes of influenza antivirals are available for clinical use: neuraminidase inhibitors (i.e., oseltamivir, zanamivir, and peramivir) and capdependent endonuclease inhibitor (i.e., baloxavir marboxil). ${ }^{4}$ However, delay in diagnostic and therapeutic procedures and development of virus resistance can lead to reduced benefits for patients. ${ }^{5-7}$

It is widely accepted that not only virus replication competence but also host immune response contribute to disease outcome in IV disease. ${ }^{8}$ Early recognition of IVs is mediated by pattern recognition receptors (PRRs) such as tolllike receptors (TLRs) and retinoic acid inducible gene-I (RIGI) in respiratory epithelial cells and alveolar macrophages. ${ }^{9-11}$ Activation of these molecules triggers signal transduction pathways, leading to the production of proinflammatory cytokines and the subsequent clearance of the virus. ${ }^{11}$ In an otherwise healthy individual, IV causes mild infections, and virus clearance can be accomplished without causing damage in the respiratory tract. ${ }^{12}$ However, IV infections caused by pandemic or highly pathogenic strains can lead to fulminant viral pneumonia in a high-risk population, including infants, young children, pregnant women, or the elderly, who progress to acute respiratory distress syndrome (ARDS) or even die. ${ }^{13,14}$ It has been shown that cytokine storms, characterized by robust secretion of proinflammatory cytokines, such as interleukin (IL)-6, IL-8, monocyte chemoattractant protein 1 (MCP-1), interferon gamma-induced protein 10 (IP-10), tumor necrosis factor- $\alpha$ (TNF- $\alpha$ ), and C-C motif chemokine ligand (CCL) -5 , played a key role in the pathogenesis of severe IV infection. ${ }^{15,16}$ These findings highlight the need for novel therapeutic options to dampen adverse host immune responses.

Received: October 28, 2020

Accepted: December 29, 2020

Published: January 7, 2021 
A

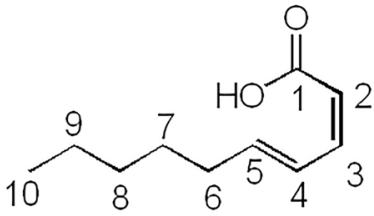

B

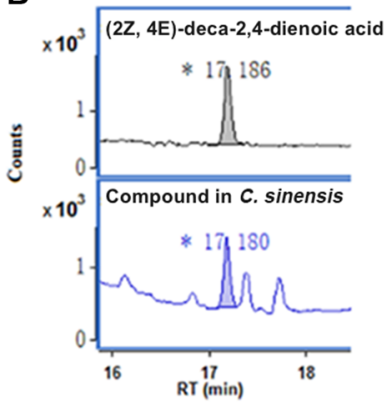

C

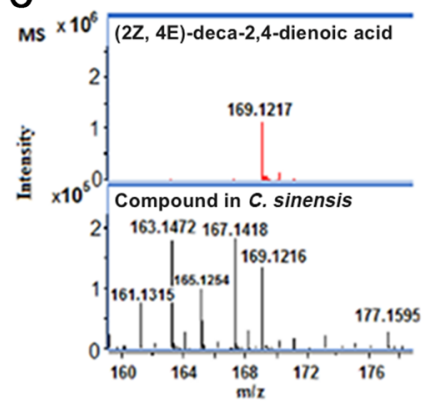

D

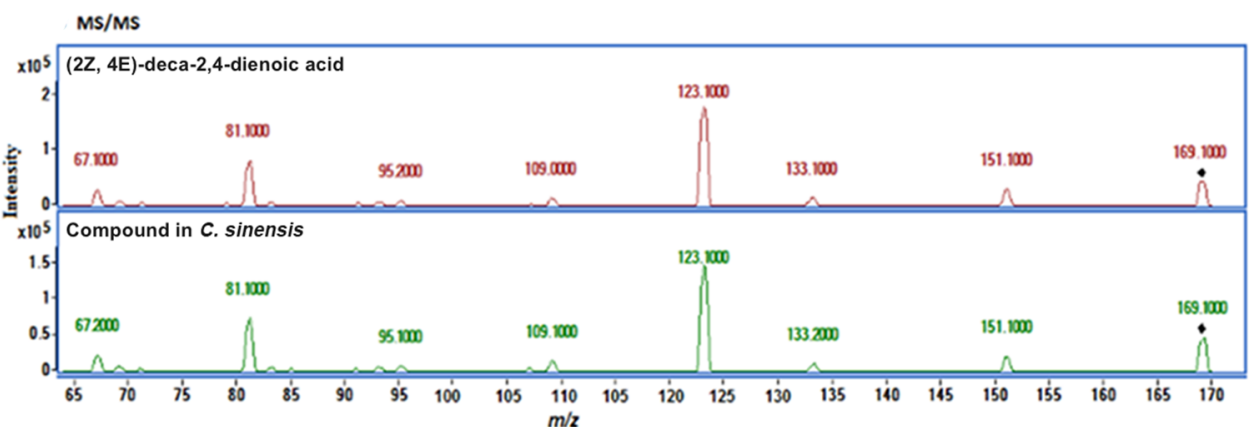

Figure 1. LC-MS/MS confirmation of the DDEA in CS by using the corresponding standard. (A) Structure of DDEA. (B) RT of DDEA in O. sinensis and CS. (C) HRMS value of DDEA in O. sinensis and CS. (D) MS/MS spectrum of DDEA in O. sinensis and CS.

Chinese Cordyceps (CS) is a famous and precious herb that has been widely used as a traditional Chinese medicine with immunomodulatory, metabolic, and tonic activity. ${ }^{17,18} \mathrm{CS}$ mainly consists of the stroma of the fungus Cordyceps sinensis (Berk.) Sacc. (family Hypocreaceae) and the dead caterpillar of Hepialus armoricanus (family Hepialidae). Ophiocordyceps sinensis, the anamporph of CS, has been cultured as an alternative of the wild CS and exhibited similar pharmacological activities. ${ }^{19,20}$ Multiple chemical constituents, such as nucleosides, amino acids, cyclopeptides, fatty acids, saccharides, mannitol, and sterols, have been isolated from this fungus. $^{21,22}$ In our previous work, numerous sphingolipids in the wild CS and their mycelia were comprehensively profiled by using the sphingolipidomic approach established in our laboratory. ${ }^{23-25}$ In a continuous study, (2Z,4E)-deca-2,4dienoic acid (DDEA) (Figure 1A) was isolated from $O$. sinensis for the first time and elucidated by means of HRMS, ${ }^{1} \mathrm{H}$ NMR, and ${ }^{13} \mathrm{C}$ NMR spectroscopic analysis. Furthermore, UHPLC-MS/MS analysis showed that this fatty acid also existed in the wild CS. To confirm its structure, DDEA was synthesized from (2E)-2-octenal by using the Still-Gennari modification of the Hornner-Wadsworth-Emmons olefination as described. ${ }^{26,27}$ Herein, we demonstrated the inhibitory effect of DDEA on influenza A (H1N1)-induced cytokine expressions in vitro and deciphered possible mechanisms underlying the anti-inflammatory effect of DDEA on PRRand IFN-dependent signaling pathways.

\section{RESULTS}

2.1. Chemistry. DDEA was isolated as a colorless oil from $O$. sinensis. Its molecular formula was established to be $\mathrm{C}_{10} \mathrm{H}_{16} \mathrm{O}_{2}$ from the HR-ESI-MS ion peak at $\mathrm{m} / z 169.1217$ $[\mathrm{M}+\mathrm{H}]^{+}\left(\right.$calcd $\left.[\mathrm{M}+\mathrm{H}]^{+} 169.1223\right)$, indicating that DDEA has three degrees of unsaturation. The ${ }^{1} \mathrm{H}$ NMR data indicate the presence of one methyl group at $\delta_{\mathrm{H}} 0.88(3 \mathrm{H}, \mathrm{t}, J=6.6$ $\mathrm{Hz})$, four methylene groups at $\delta_{\mathrm{H}} 2.14(2 \mathrm{H}, \mathrm{q}), 1.38-1.48$ $(2 \mathrm{H}, \mathrm{m})$, and $1.28-1.39(4 \mathrm{H}, \mathrm{m})$, and four olefinic groups at $\delta_{\mathrm{H}} 7.35(1 \mathrm{H}, \mathrm{ddd}, J=11.3,15.0,1.0 \mathrm{~Hz}, \mathrm{H}-4), 6.66(1 \mathrm{H}, \mathrm{t}, J=$ $11.3 \mathrm{~Hz}, \mathrm{H}-3), 6.11(1 \mathrm{H}, \mathrm{dt}, J=15.0,7.5 \mathrm{~Hz}, \mathrm{H}-5)$, and 5.57 $(1 \mathrm{H}, \mathrm{d}, J=11.3 \mathrm{~Hz}, \mathrm{H}-2)$ (Figure $\mathrm{S} 1$ ). The ${ }^{13} \mathrm{C}$ NMR data revealed 10 carbon signals, corresponding to one methyl carbon $\left(\delta_{\mathrm{c}} 14.0\right)$, four methylene carbons $\left(\delta_{\mathrm{c}} 33.0,31.5,28.5\right.$, and 22.5), four olefinic carbons $\left(\delta_{c} 147.7,147.2,127.0\right.$, and 114.4), and one carbonyl carbon $\left(\delta_{c}\right.$ 171.6) (Figure S2). Configuration assignment was based on the multiplicities and vicinal coupling constants of the compound from ${ }^{1} \mathrm{H}$ NMR spectrum. The signals at $\delta_{\mathrm{H}} 5.57(1 \mathrm{H}, \mathrm{d}, J=11.3 \mathrm{~Hz}, \mathrm{H}-2)$ and $\delta_{\mathrm{H}} 6.66(1 \mathrm{H}, \mathrm{t}, J=11.3 \mathrm{~Hz}, \mathrm{H}-3)$ were assigned to two olefinic protons of a double bond with $Z$ geometry, and the proton at $\delta_{\mathrm{H}} 5.57(\mathrm{~d}, J=11.3 \mathrm{~Hz})$ was assigned to the $\alpha$ position of carbonic acid. The coupling constant $(J=15.0 \mathrm{~Hz})$ of $\delta_{\mathrm{H}} 7.35$ $(1 \mathrm{H}, \mathrm{ddd}, J=15.0,11.3,1.0 \mathrm{~Hz}, \mathrm{H}-4)$ and $\delta_{\mathrm{H}} 6.11(1 \mathrm{H}, \mathrm{d} t, J=$ 15.0, $7.5 \mathrm{~Hz}, \mathrm{H}-5)$ clearly indicated an $E$ geometry for the double bond.

To confirm its structure and afford enough samples for bioactivity evaluation, DDEA was synthesized from (2E)-2octenal, as shown in Scheme 1. The unsaturated (2E)-2- 
Scheme 1. Synthetic Route for DDEA
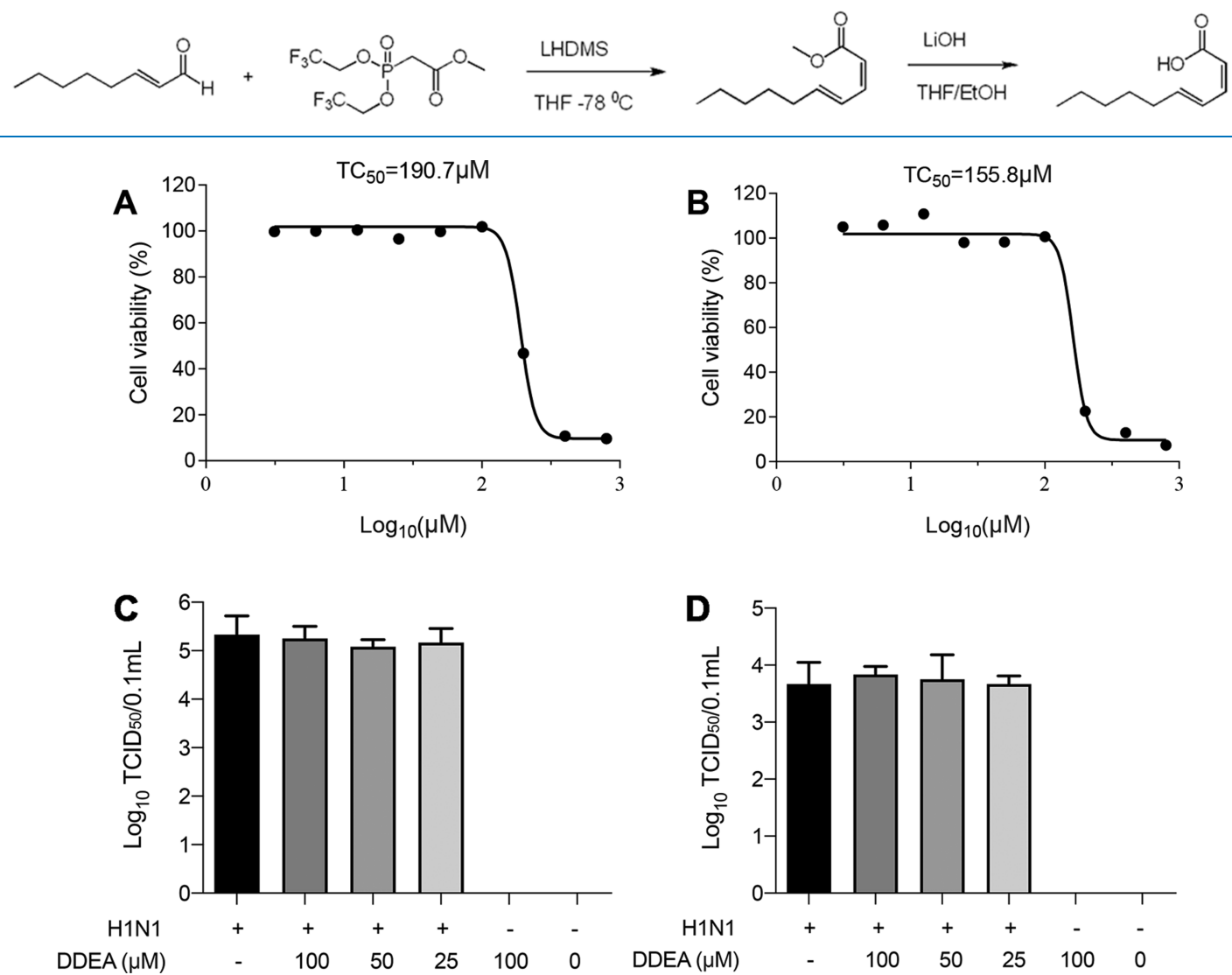

Figure 2. Cytotoxicity and antiviral effect of DDEA in A549 cells and U937 macrophages. For cytotoxicity assay, A549 cells (A) and U937 macrophages (B) were incubated with twofold serial dilution of DDEA for $48 \mathrm{~h}$, followed by MTT staining. The absorbance at a wavelength of 490 $\mathrm{nm}$ was measured. In the $\mathrm{TCID}_{50}$ assay, A549 cells (C) and U937 macrophages (D) were infected by A/Puerto Rico/8/34 (H1N1) (PR8) virus at a multiplicity of infection (MOI) of 1 with indicated concentrations of DDEA. Viral replication in culture supernatants was determined at $24 \mathrm{~h}$ postinfection (hpi). Results are presented as the mean \pm SD from three independent experiments.

octenal was converted to $(2 Z, 4 E)$-conjugated ester by using the Still-Gennari modification of the Hornner-WadsworthEmmons olefination. Following hydrolysis of the conjugated ester was performed by lithium hydroxide in ethanol and tetrahydrofuran to afford DDEA. Its HRMS, ${ }^{1} \mathrm{H} \mathrm{NMR}$, and ${ }^{13} \mathrm{C}$ NMR spectrum are in accordance with the spectra of the compound isolated from $O$. sinensis.

We next performed UHPLC-MS/MS analysis to confirm the presence of DDEA in CS. Comparison of chromatographic retention time showed that a peak of CS has the same RT (RT $=17.18 \mathrm{~min}$ ) value as with DDEA (Figure $1 \mathrm{~B}$ ). Then, the compound was confirmed by comparing the high-resolution MS and MS/MS spectra with DDEA. Results showed that high-resolution MS $(m / z$ 169.12) (Figure 1C) and fragment ions (such as $m / z 151.1,133.1,123.1,109.1,95.1,81.1$, and 67.1) (Figure 1D) are consistent with those of DDEA. Therefore, we prove that DDEA is present in the CS.

2.2. Cytotoxicity and Antiviral Activity of DDEA in A549 Cells and U937-Derived Macrophages. The 3-[4, 5dimethylthiazol-2-yl]-2, 5 diphenyl tetrazolium bromide (MTT) assay was employed to evaluate the cytotoxicity in A549 cells and U937 macrophages. The results showed that DDEA did not cause cytotoxicity at the concentration up to $100 \mu \mathrm{M}$ with median toxic concentration $\left(\mathrm{TC}_{50}\right)$ values found to be 190.7 and $155.8 \mu \mathrm{M}$ for A549 cells and U937 macrophages, respectively (Figure 2A,B). The anti-influenza activity of DDEA was then examined in MDCK cells by using $\mathrm{CPE}$ reduction assay and further quantified by MTT staining. The DDEA did not reduce the PR8-induced CPE or the cell viability loss detected by MTT with the median inhibitory concentration $\left(\mathrm{IC}_{50}\right)>100 \mu \mathrm{M}$ (data not shown). We next measured the infectious virus in A549 cell culture supernatants by the $50 \%$ tissue culture infective dose $\left(\mathrm{TCID}_{50}\right)$ assay. No significant difference in the virus titer was observed in infected cells treated with or without DDEA (Figure 2C,D). These results suggest that DDEA may not inhibit IV replication.

2.3. Inhibitory Effect of DDEA on Proinflammatory Cytokines. To understand the inhibitory effect of DDEA on proinflammatory responses, we measured mRNA and corresponding protein levels of various cytokines in PR8-infected A549 cells and U937 macrophages. The mRNA and protein levels of TNF- $\alpha$, IFN- $\alpha$, IFN- $\beta$, IL-6, CXC chemokine ligands (CXCL)-8/IL-8, CCL-2/MCP-1, CXCL-10/IP-10, CCL-3/ macrophage inflammatory protein (MIP)- $1 \alpha$, CCL-4/MIP-1 $\beta$ were upregulated in both cells at 24 hpi (Figures 3, 4). At both levels, DDEA showed a significant inhibition on PR8-induced cytokine production in a dose-dependent manner in A549 cells (Figure 3A,B). Similar trends were also observed in PR8infected U937 macrophages with the treatment of DDEA (Figure 4A,B). These results suggest that DDEA exhibits potent anti-inflammatory effect against $\mathrm{H} 1 \mathrm{~N} 1$ infection. 

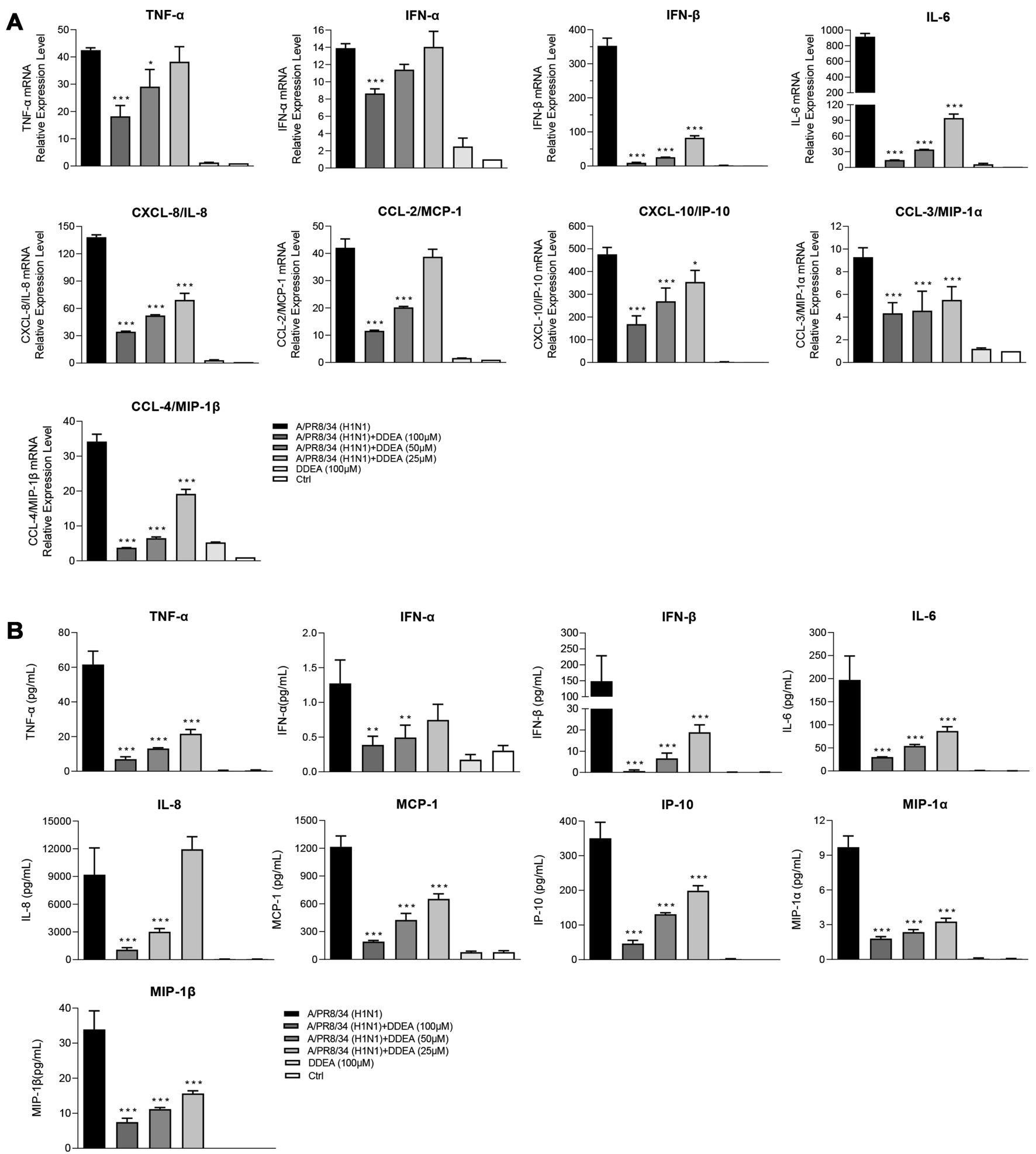

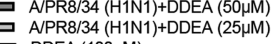
DDEA $(100 \mathrm{MM})$

Figure 3. Inhibitory effect of DDEA on the proinflammatory cytokine expressions in H1N1-infected A549 cells. After PR8 virus (1 MOI) absorption for $2 \mathrm{~h}$, infected cells were treated with or without indicated concentrations of DDEA for $24 \mathrm{~h}$. (A) mRNA expression levels of TNF- $\alpha$, IFN- $\alpha$, IFN- $\beta$, IL-6, CXCL-8/IL-8, CCL-2/MCP-1, CXCL-10/IP-10, CCL-3/MIP-1 $\alpha$, and CCL-4/MIP-1 $\beta$ were determined by real-time RTPCR. (B) Levels of proinflammatory cytokines in the culture supernatants were measured by a Bio-Plex assay. Data represented the mean \pm SD from three independent experiments. $*, p<0.05$, **, $p<0.01$, ***, $p<0.001$, compared with virus-infected cells without DDEA treatment.

\subsection{Effect of DDEA on H1N1-Induced Innate Cellular}

Signaling Pathway. Because PRR-mediated signaling pathways regulate cytokine expressions, we next investigated whether the inhibitory effect of DDEA on cytokine levels would be related to its impact on PRR pathways. As expected,
DDEA treatment significantly decreased the levels of TLR-3 and RIG-I in PR8-infected A549 cells (Figure 5A,B). Also, phosphorylation of the downstream interferon regulatory factors 3 (IRF-3) and p65 was also markedly downregulated by DDEA (Figure 5C,D). Because we found that DDEA 
A
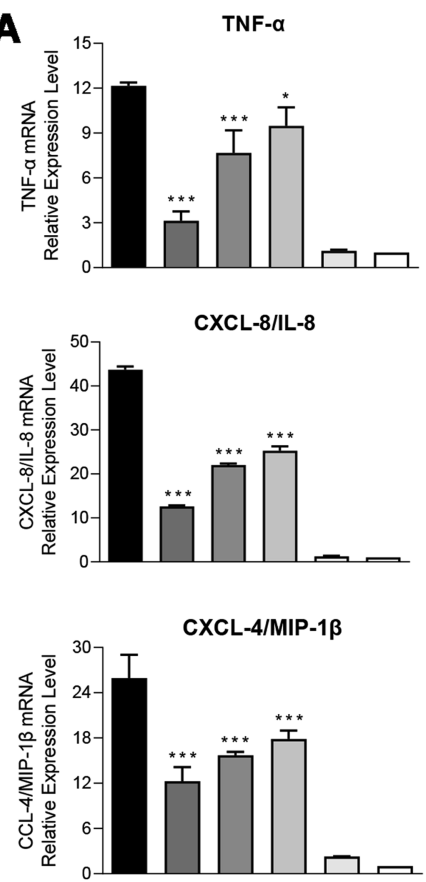

B

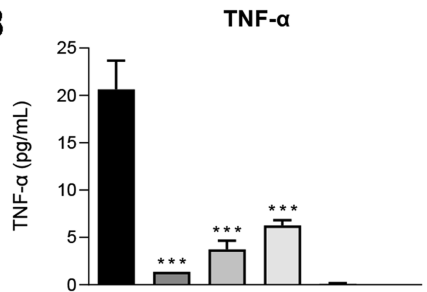

IL-8
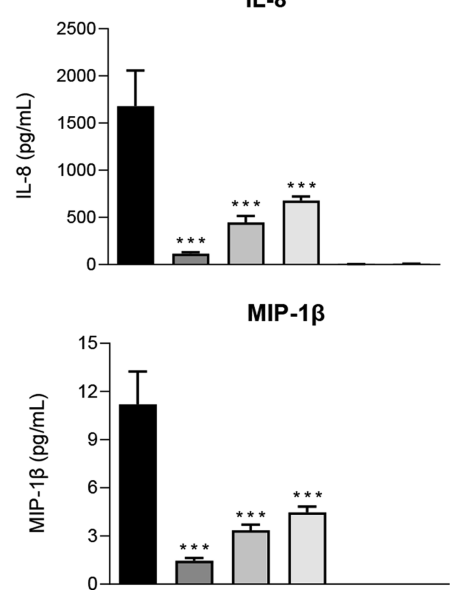
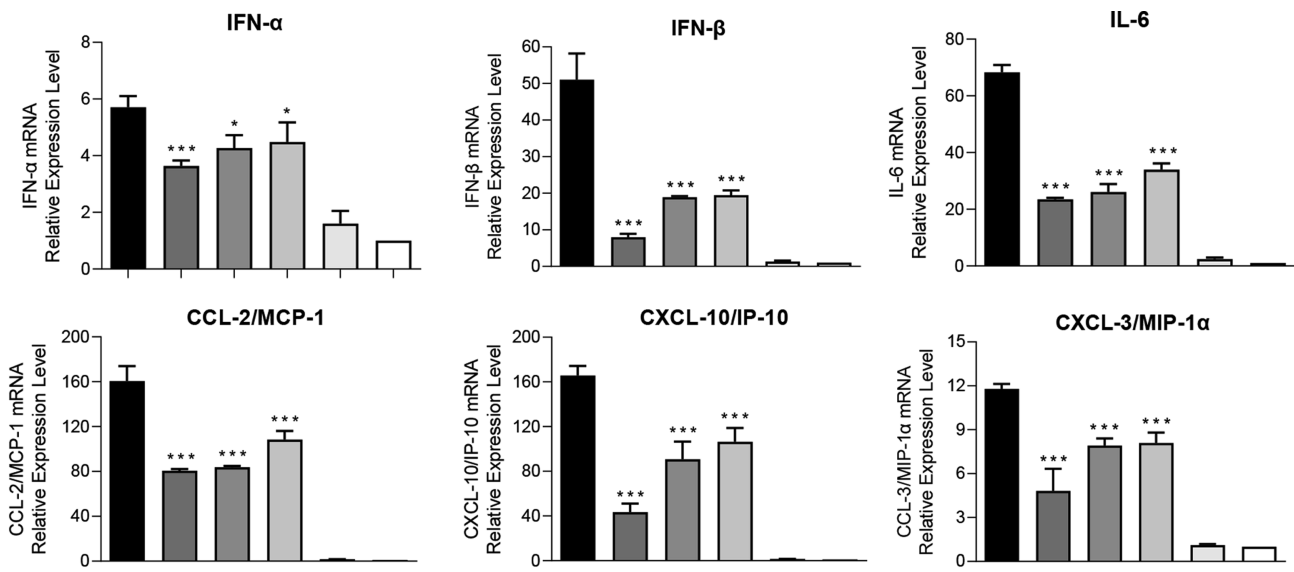

APR8/34 (H1N1)

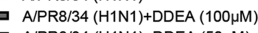

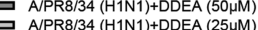

DDEA $(100 \mu \mathrm{M})$

Figure 4. Inhibitory effect of DDEA on the proinflammatory cytokine expressions in H1N1-infected U937 macrophages. The PR8 virus at MOI of 1 was first allowed to bind to U937 macrophages for $2 \mathrm{~h}$. After the inoculum was removed, infected cells were treated with or without indicated concentrations of DDEA for another $24 \mathrm{~h}$. (A) mRNA levels of TNF- $\alpha$, IFN- $\alpha$, IFN- $\beta$, IL-6, CXCL-8/IL-8, CCL-2/MCP-1, CXCL-10/IP-10, CCL-3/MIP-1 $\alpha$, and CCL-4/MIP-1 $\beta$ were detected by real-time RT-PCR. (B) Protein levels of proinflammatory cytokines in the culture supernatant were measured by a Bio-Plex assay. Data represented the mean $\pm \mathrm{SD}$ from three independent determinations. $*, p<0.05, * *, p<0.01$, $* * *$, and $p<0.001$, compared with virus-infected cells without DDEA treatment.

attenuated the type I IFN expression, we speculated that the phosphorylation of IFN signaling molecules may also be affected. Accordingly, we found that the phosphorylated signal transducer and activator of transcription 2 (STAT2) was also remarkably inhibited by DDEA (Figure 5E). The DDEA at doses of 25 and $50 \mu \mathrm{M}$ inhibited these host sensors at similar levels, suggestive of an unapparent dose-dependent manner.
Designing a wider range of dilution, such as fivefold serial dilution, may result in a better trend toward inhibition for DDEA.

\section{DISCUSSION}

The CS contains plenty of saturated and polyunsaturated fatty acids (PUFA). ${ }^{21}$ Guo et al. reported 17 fatty acids and their 

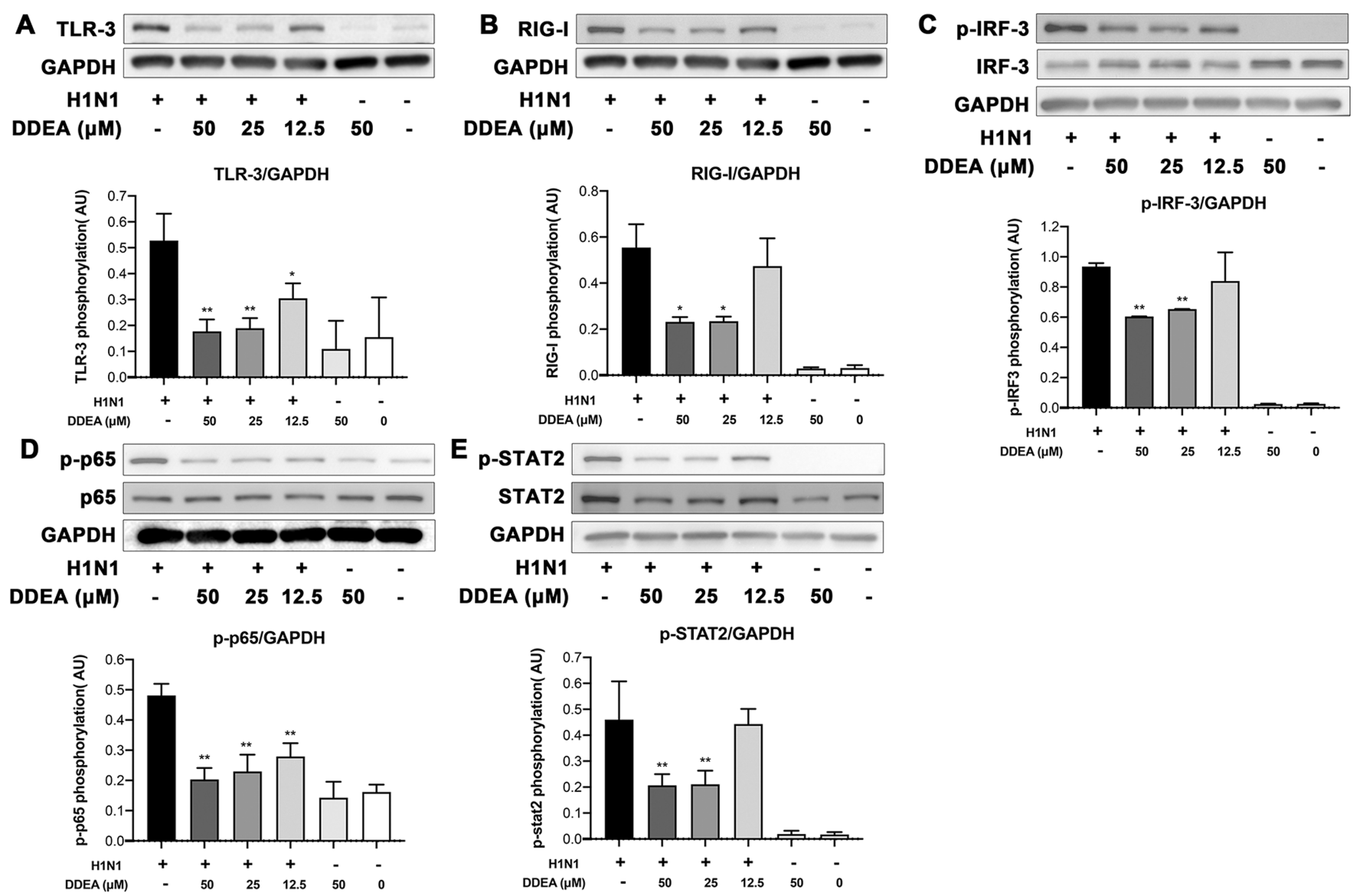

Figure 5. DDEA inhibits PRRs- and IFN-mediated signaling pathways activated by H1N1 in A549 cells. The A549 cells were infected by PR8 at MOI of 1 for $2 \mathrm{~h}$. The inoculum was then removed and replaced with medium containing indicated concentrations of DDEA. After $24 \mathrm{~h}$ of incubation, total cell lysates were collected and the protein levels of (A) TLR-3, (B) RIG-I, (C) phosphorylated (p)-IRF-3, (D) p-p65, and (E) pSTAT2 were measured by western blot assay. The glyceraldehyde 3-phosphate dehydrogenase (GAPDH) was used as a housekeeping control.

relative and absolute contents via gas chromatography-mass spectrometry (GC-MS) with $\mathrm{C}_{16: 0}, \mathrm{C}_{18: 0}, \mathrm{C}_{18: 1}, \mathrm{C}_{18: 2}$, and $\mathrm{C}_{18: 3}$ as major constituents in natural O. sinensis. ${ }^{28}$ In another study, Guo's group compared fatty acids' contents between wild and cultured $\mathrm{CS}^{29}$ In addition, Yang et al. reported 10 fatty acids, namely, lauric acid, myristic acid, pentadecanoic acid, palmitoleic acid, palmitic acid, linoleic acid, oleic acid, stearic acid, docosanoic acid, and lignoceric acid in natural and cultured CS using pressurized liquid extraction, trimethylsilyl derivatization, and GC-MS analysis. ${ }^{30}$ The CS extract and the acidic polysaccharide isolated from Cordyceps militaris have been proven effective in alleviating disease severity in IVinfected mice by modulating immune functions. ${ }^{31,32}$ Besides, many other compounds with anti-inflammatory or antiviral properties, such as cordycepin, nucleosides, cyclopeptides, sterols, sphingolipids, and fatty acids, are also present in Cordyceps species. ${ }^{17,21}$ It has been shown that PUFA inhibited IV replication and exhibited pharmacological activity in innate and adaptive antiviral responses, as well as inflammation control. ${ }^{33}$ In this study, we chemically synthesized a conjugated PUFA DDEA identified from CS and found that DDEA did not inhibit H1N1 virus replication but attenuated proinflammatory responses by reducing levels of a number of cytokines. Additionally, DDEA inhibited activations of TLR-3-, RIG-I-, and type I IFN-activated signaling pathways.

Highly pathogenic IVs such as $1918 \mathrm{H} 1 \mathrm{~N} 1$ and avian H5N1 and $\mathrm{H} 7 \mathrm{~N} 9$ viruses often cause an inflammatory cytokine storm that is responsible for the development of severe pneumonia, ARDS, or even death. Blockage of cytokine induction is the most direct tactic to blunt the cytokine storm. Aberrant cytokine responses can also be mitigated by inhibitors targeting components in innate immune signaling, such as antagonists of PRRs and kinases. ${ }^{34,35}$ In the present study, we found that DDEA did not suppress virus replication in lung epithelial cells and macrophages, the primary targets for IV, nor did it inhibit the phosphorylation of extracellular signal-regulated kinase (ERK), protein kinase B (PKB, Akt), and p38 used by IV to facilitate its entry, RNP translocation, and vRNA synthesis. ${ }^{36,37}$

Following IV infection, the viral ssRNA is sensed by TLR family members, such as TLR-3,-7, and -8, and RIG-I like receptors, such as RIG-I and melanoma differentiationassociated gene 5 (MDA5). ${ }^{38}$ Recognition by these PRRs leads to the activation of nuclear factor $-\kappa \mathrm{B}(\mathrm{NF}-\kappa \mathrm{B})$ and IRF-3, resulting in the induction of proinflammatory cytokines such as TNF- $\alpha$, IL- $1 \beta$, IL- 6 , and IFNs. ${ }^{38}$ In an appropriate immune response, expressions of proinflammatory cytokines facilitate viral clearance, which was followed by a resolution of inflammation, tissue repair and a return to homeostasis. ${ }^{39}$ However, in severe influenza cases, hyperactivated innate signaling cascades orchestrate uncontrolled inflammatory responses, contributing to severe lung tissue injury. ${ }^{40,41}$ Previous studies found that administration of TLR4 antagonists reduced levels of proinflammatory cytokines such as TNF- $\alpha$, IL- $1 \beta$, IL-6, and keratinocyte chemoattractant (KC) in 


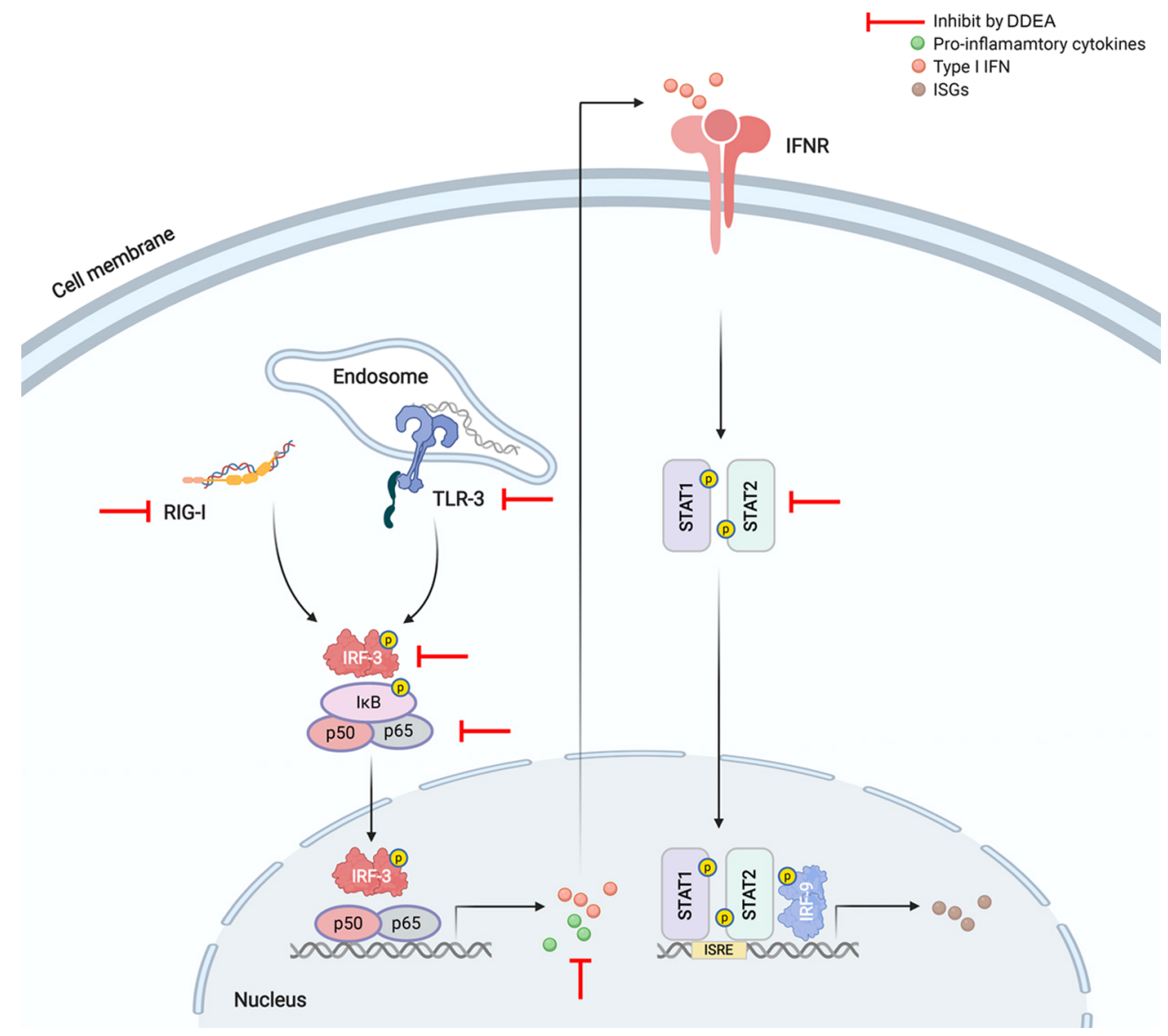

Figure 6. Schematic diagram of mechanisms underlying the anti-inflammatory effect of DDEA on innate immune signaling pathways. Influenza H1N1 virus activates the TLR-3-, RIG-I-, and IFN-dependent signaling pathways. DDEA treatment inhibits a range of molecules in these pathways, including TLR-3, RIG-I, $p$-IRF-3, $p$-p65, and $p$-STAT2.

mice challenged with lethal IV. ${ }^{42,43} \mathrm{Li}$ et al. recently demonstrated that polysaccharides isolated from Radix isatidis inhibited IL-6 and CCL-5 expressions by blocking upstream TLR3 in vitro. ${ }^{44}$ Small interference RNA (siRNA)-mediated RIG-I silencing resulted in significant decreased levels of TNF$\alpha$, IFN- $\beta$, IFN- $\lambda 1$, and IP-10 in H5N1- and H1N1-infected human macrophages. ${ }^{45}$ These findings indicate that TLRs and RIG-I are required for inductions of proinflammatory cytokines. Comparably, we found that the downregulation of TLR-3, RIG-I, and the downstream $p$-IRF-3 and $p$-p65 by DDEA resulted in blunted cytokine responses, which suggests that DDEA may serve as a potential immunomodulator by regulating TLR-3- and RIG-I-dependent signaling pathways. The type I (IFN- $\alpha, \beta)$, II (IFN- $\gamma$ ), and III (IFN- $\lambda 1-3)$ IFNs are well-known cytokines essential to limit the replication and dissemination of IVs. The type I IFN induction can be completely shut down after dual knockdown of RIG-I and TLR-3, indicating that TLR-3 and RIG-I contribute to the maximum IFN production following IV infection. ${ }^{46}$ Therefore, the decrease in levels of type I IFNs by DDEA may be the consequence of inhibitions of TLR-3 and RIG-I. The type I IFN induced by PPRs binds to the interferon $\alpha$ and $\beta$ receptor subunit 1 (IFNAR1)/IFNAR2 receptor, which initiates the formation of the interferon-stimulated gene factor 3 (ISGF3) complex comprising IRF9, $p$-STAT1, and $p$-STAT2. ${ }^{47}$ The ISGF3 is then translocated to the nucleus and drives the transcription of various antiviral genes, namely, IFN-stimulated genes (ISGs), such as the Mx family, interferon-induced transmembrane protein family (IFITMs), cholesterol 25hydroxylase $(\mathrm{CH} 25 \mathrm{H})$, and the tripartite motif-containing proteins (TRIM). ${ }^{38}$ Although we found that the IFNs and $p$ STAT2 were downregulated with DDEA treatment, we did not observe a significant increase in viral replication (Figure 4). It is possible that the impaired IFN/STAT signaling induced by DDEA may delay the clearance of virus. Therefore, combination of DDEA and an antiviral agent, rather than DDEA alone, may be a better therapeutic strategy for treating IV infection. In addition, the type I IFN response not only induces an important antiviral state but also activates various proinflammatory pathways mediated by phosphoinositide 3kinase (PI3K), NF- $\kappa \mathrm{B}$, or mitogen-activated protein kinase (MAPK). ${ }^{48}$ An in vivo study reported that although IFN- $\alpha$ treatment restricted IV replication, it exacerbated disease by inducing proinflammatory cytokine production and promoting innate cell recruitment. ${ }^{49}$ It is conceivable that the inhibition of type I IFN by DDEA may help in reducing such adverse immune consequences.

In conclusion, we demonstrate that DDEA inhibits proinflammatory cytokine expressions by interrupting TLR-3, RIG-I, and IFN-signaling pathways activated by IV (Figure 6). The results of this study indicate that DDEA may potentially be used as an anti-inflammatory therapy for the treatment of IV infections. 


\section{MATERIALS AND METHODS}

4.1. Chemicals and Materials. Solvents and reagents were obtained from a commercial supplier. For simplicity, (2E)-2-octenal, lithium bis(trimethylsilyl)amide (LiHDMS), trimethyl phosphonoacetate, bis(2,2,2-trifluoroethyl) (methoxycarbonylmethyl) phosphonate, chloroform, tetrahydrofuran, dichloromethane, ethyl acetate (EtOAc), hydrochloric acid, methanol $(\mathrm{MeOH})$, sodium bicarbonate $\left(\mathrm{NaHCO}_{3}\right)$, ammonium chloride $\left(\mathrm{NH}_{4} \mathrm{Cl}\right)$, sodium chloride $(\mathrm{NaCl})$, magnesium sulfate $\left(\mathrm{MgSO}_{4}\right)$, lithium hydroxide $(\mathrm{LiOH})$, trimethylamine, $n$-hexane, petroleum ether, and acetonitrile (ACN) were purchased from TCI or 9dingchem (Shanghai, China). NMR solvent $\mathrm{CDCl}_{3}$ was purchased from Cambridge Isotope Laboratories, Inc. (Andover, MA, USA). Paecilomyces hepiali and CS were purchased from commercial sources. Deionized water was prepared in our laboratory by a Millipore Milli-Qplus system (Millipore, Bedford, MA, USA). Nuclear magnetic resonance (NMR) spectra were acquired on a Bruker Ascend 600 NMR spectrometer (Bruker, Zurich, Switzerland) at 600 $\mathrm{MHz}$ for ${ }^{1} \mathrm{H}$ NMR and $150 \mathrm{MHz}$ for ${ }^{13} \mathrm{C}$ NMR. HRMS and LC-MS/MS spectrum were obtained on an Agilent 6550 QTOF mass spectrometer (Agilent, Santa Clara, CA, USA) in positive ion mode. Thin layer chromatography (TLC) was performed on silica gel $60 \mathrm{~F}_{254}$ plates and $\mathrm{RP}-18 \mathrm{~F}_{254 \mathrm{~S}}$ plates (200 $\mu \mathrm{M}$ thick, Merck KGaA, Germany). Column chromatography was conducted with Davisil silica gel (40-63 $\mu \mathrm{M}$, Grace, Columbia, MD, USA) and Waters ODS (55-105 $\mu \mathrm{M}$, Miford, MA, Ireland).

4.2. Cell Lines and Virus. Human lung carcinoma A549 cells, human leukemia U937 cells, and Madin-Darby canine kidney (MDCK) cells were purchased from American Type Culture Collection (ATCC). The A549 and MDCK cells were cultured in Dulbecco's Modified Eagle's Medium (DMEM, Gibco) supplemented with $10 \%$ fetal bovine serum (FBS) at $37{ }^{\circ} \mathrm{C}$. The U937 cells were cultured in RPMI 1640 supplemented with $10 \%$ heat-inactivated FBS, $2.5 \mathrm{mM}$ glutamine, and $10 \mathrm{mM}$ HEPES at $37{ }^{\circ} \mathrm{C}$ and differentiated into macrophages-like cells in the presence of $100 \mathrm{nM}$ of phorbol myristate acetate (PMA) (Sigma) for $48 \mathrm{~h}$. Influenza H1N1 virus PR8 strain, A/Puerto Rico/8/34, was purchased from ATCC, propagated in the allantoic cavities of chicken eggs and titrated in MDCK cells.

4.3. Extraction and Isolation of DDEA. The dried powder of $P$. hepiali (166.6 g) was extracted with chloroform three times in an ultrasonic bath. The combined solutions were concentrated in a rotary evaporator under reduced pressure to afford a concentrate $(30 \mathrm{~mL})$. The concentrate was subjected to a silica gel column eluted with $n$-hexane-ethyl acetate (95:5 $\rightarrow 0: 100, \mathrm{v} / \mathrm{v})$, followed by chloroform-methanol-water $(9: 1: 0.1 \rightarrow 8: 2: 0.2, \mathrm{v} / \mathrm{v})$ to yield 38 fractions. Fraction 5 (1.9 g) was further separated by silica gel column chromatography using petroleum ether-ethyl acetate $(95: 5 \rightarrow 0: 100, \mathrm{v} / \mathrm{v})$ to give 12 subfractions. Fraction 5-5 (0.9 g) was rechromatographed on silica gel ( $n$-hexane-ethyl acetate, 94:6 $\rightarrow$ 50:50, $\mathrm{v} / \mathrm{v})$ to give fraction 5-5-4 (100 mg). Fraction 5-5-4 was further subjected to silica gel column chromatography eluted with petroleum ether-ethyl acetate $(94: 6 \rightarrow 50: 50, \mathrm{v} / \mathrm{v})$ to afford fraction 5-5-4-1 (57 mg). The last subfraction was purified by ODS column chromatography (methanol-water, $70: 30 \rightarrow 100: 0, \mathrm{v} / \mathrm{v})$ to give DDEA $(9 \mathrm{mg}) .{ }^{1} \mathrm{H}$ NMR $(600$ $\left.\mathrm{MHz} \mathrm{CDCl}_{3}\right): \delta 7.35(\mathrm{dd}, J=11.3,15.2 \mathrm{~Hz}, 1 \mathrm{H}, \mathrm{H}-4), 6.66(\mathrm{t}$, $J=11.3 \mathrm{~Hz}, 1 \mathrm{H}, \mathrm{H}-3), 6.11(\mathrm{dt}, J=15.2,7.3 \mathrm{~Hz}, 1 \mathrm{H}, \mathrm{H}-5)$, $5.57(\mathrm{~d}, J=11.3 \mathrm{~Hz}, 1 \mathrm{H}, \mathrm{H}-2), 2.17(\mathrm{q}, 2 \mathrm{H}), 1.40-1.45(\mathrm{~m}$, $2 \mathrm{H}), 1.28-1.32(\mathrm{~m}, 4 \mathrm{H}), 0.88(\mathrm{t}, J=6.9 \mathrm{~Hz}, 3 \mathrm{H}) ;{ }^{13} \mathrm{C} \mathrm{NMR}$ $\left(150 \mathrm{MHz}, \mathrm{CDCl}_{3}\right): \delta 171.6,147.7,147.2,127.0,114.4,33.0$, 31.5, 28.5, 22.5, 14.1. HRMS-ESI $(m / z):[\mathrm{M}+\mathrm{H}]^{+}$calcd for $\left[\mathrm{C}_{10} \mathrm{H}_{17} \mathrm{O}_{2}\right]^{+}, 169.1223$; found, 169.1217 .

4.4. Synthesis of DDEA. A solution of bis(2,2,2trifluoroethyl) (methoxycarbonylmethyl) phosphonate (1.6 g, $5.0 \mathrm{mmol})$ and 18-crown-6 (12.2 $\mathrm{g}, 46.5 \mathrm{mmol})$ in tetrahydrofuran (THF) $(100 \mathrm{~mL})$ at $0{ }^{\circ} \mathrm{C}$ was treated with a 1.3 $\mathrm{M}$ solution of lithium bis(trimethylsilyl)amide (LiHDMS) in THF $(3.9 \mathrm{~mL})$. The reaction mixture was stirred for $15 \mathrm{~min}$ before a solution of $(2 E)$-2-octenal $(0.6 \mathrm{~mL}, 4.0 \mathrm{mmol})$ was added at $0{ }^{\circ} \mathrm{C}$. The reaction mixture was stirred for $2 \mathrm{~h}$, saturated aqueous $\mathrm{NH}_{4} \mathrm{Cl}(40 \mathrm{~mL})$ and saturated aqueous $\mathrm{NaCl}(80 \mathrm{~mL})$ were added, and stirred for another $2 \mathrm{~h}$. Then, the reaction mixture was extracted with EtOAc $(3 \times 50 \mathrm{~mL})$, the organic layer was dried $\left(\mathrm{MgSO}_{4}\right)$, filtered, and concentrated in vacuo. The residue was purified by flash silica gel chromatography (hexane/ethyl acetate 100:1, v/v) to give a colorless liquid. Then, a solution of methyl $(2 Z, 4 E)$-deca-2,4dienoate $(126.3 \mathrm{mg}, 0.7 \mathrm{mmol})$ in $33 \% \mathrm{THF}-\mathrm{EtOH}(6.0 \mathrm{~mL})$ was treated with aqueous $0.8 \mathrm{M} \mathrm{LiOH}(4.0 \mathrm{~mL})$, and the reaction mixture was stirred at $25{ }^{\circ} \mathrm{C}$ for $15 \mathrm{~h}$. The reaction mixture was acidified with $12 \mathrm{M} \mathrm{HCl}$ and treated with water $(50 \mathrm{~mL})$ and extracted with EtOAc $(3 \times 50 \mathrm{~mL})$. The organic layer was dried with $\mathrm{MgSO}_{4}$, filtered, and concentrated in vacuo. The residue was purified by flash silica gel chromatography (hexane/ethyl acetate $5: 1, \mathrm{v} / \mathrm{v}$ ) to give a colorless liquid $(77.5 \mathrm{mg}, 72 \%) . R_{f}=0.5$ (hexane/ethyl acetate $3: 1, \mathrm{v} / \mathrm{v})$. Its HRMS, ${ }^{1} \mathrm{H} \mathrm{NMR}$, and ${ }^{13} \mathrm{C}$ NMR spectral data are in good agreement with those of the compound isolated from $O$. sinensis.

4.5. Detection of DDEA in the CS. Dried CS $(0.3 \mathrm{~g})$ was extracted with $\mathrm{MeOH}(2 \mathrm{~mL})$ twice in an ultrasonic bath for $30 \mathrm{~min}$; the combined solutions were concentrated in a pressure-blowing concentrator to afford a concentrate (250 $\mu \mathrm{L})$. Then, $10 \mu \mathrm{L}$ of the sample was injected into an Agilent Zorbax Eclipse Plus C18 $(1.8 \mu \mathrm{m}, 2.1 \times 150 \mathrm{~mm})$ column on an Agilent 6550 ultrahigh-performance liquid chromatography-ultrahigh definition-quadrupole time-of-flight mass spectrometry (UHPLC-UHD-Q-TOF-MS). The mobile phase was composed of $1 \%$ formic acid (FA) in water (A) and $1 \%$ FA in $\mathrm{ACN}(\mathrm{B})$, and the gradient elution was performed at a flow rate of $0.35 \mathrm{~mL} / \mathrm{min}$ as follows: $5 \% \mathrm{~B}$ for $3 \mathrm{~min}, 5-68 \% \mathrm{~B}$ over $20 \mathrm{~min}$, and $100 \% \mathrm{~B}$ for $5 \mathrm{~min}$. The dry-gas $\left(\mathrm{N}_{2}\right)$ temperature and flow rate were $325^{\circ} \mathrm{C}$ and $9 \mathrm{~L} / \mathrm{min}$, respectively. The LC/ MS data of unknown compound were analyzed based on peak retention time, accurate mass, and fragment ions. The MS spectra were acquired in the positive mode.

4.6. Cytotoxicity Assay. The A549 and PMA-differentiated U937 cell monolayers were rinsed twice with PBS. After removal of the wash buffer, the twofold serially diluted DDEA was added to cells and incubated for $48 \mathrm{~h}$. After removing the supernatant, cell culture plates underwent cytotoxicity assessment by the MTT assay as previously described. ${ }^{50}$ The $\mathrm{TC}_{50}$ was calculated by the GraphPad Prism 8.0 software.

4.7. Antiviral Assay. In the CPE reduction assay and MTT assay, the MDCK cell monolayers in 96-well plates were inoculated with PR8 at a MOI of 0.001 at $37^{\circ} \mathrm{C}$ for $2 \mathrm{~h}$. After the inoculum was removed, the cells were incubated with twofold serially diluted DDEA. After $72 \mathrm{~h}$, the infected cells presented $100 \%$ cytopathogenic effect (CPE) under the 
microscope. The percentage of CPE in infected cells with DDEA treatment was recorded. The medium was then removed and replaced by $1 \mathrm{~mL}$ of $0.5 \mathrm{mg} / \mathrm{mL}$ MTT solution. Following $4 \mathrm{~h}$ incubation, MTT was removed and $100 \mu \mathrm{L}$ dimethyl sulfoxide (DMSO) was added to each well. The absorbance was measured at a wavelength of $490 \mathrm{~nm}$ using a microplate reader (Synergy HT, Bio-Tek). The $\mathrm{IC}_{50}$ of DDEA was calculated by the GraphPad Prism 8.0 software.

In the virus titration experiment, confluent monolayers of A549 cells and U937 macrophages were rinsed twice with PBS and subsequently infected with PR8 at a MOI of 1 for $2 \mathrm{~h}$ at 37 ${ }^{\circ} \mathrm{C}$. After virus adsorption, the inoculum was removed and supplemented with culture medium containing twofold serially diluted DDEA. After $24 \mathrm{~h}$ of incubation, supernatants were collected for viral titration using the $\mathrm{TCID}_{50}$ assay and cytokine measurement by the Bio-Plex assay, while cell layers were collected for RNA isolation.

4.8. RNA Isolation and Reverse Transcription RealTime Quantitative PCR. Total RNA was isolated using FastPure Cell/Tissue Total RNA Isolation Kit (Vazyme Biotech) according to the manufacturer's protocol. cDNA was generated from total RNA using the PrimeScript RT-PCR Kit (Takara). Real-time quantitative PCR was performed with target gene-specific TaqMan probes and primers by using an Applied Biosystems 7500 system. Each primer and probe used in this study is listed in Supporting Information Table S1. Relative quantification of gene expression was calculated by the $2^{-\Delta \Delta C t}$ method with GAPDH as the endogenous reference.

4.9. Proinflammatory Cytokine Measurement in the Culture Supernatant. Proinflammatory cytokine levels in cell culture supernatants were detected using Bio-Plex Pro Human Cytokine Screening Panel (Bio Rad) according to the manufacturer's instructions. The test plate was analyzed using a Bio-Plex Luminex 200 XYP instrument (Bio-Rad Laboratories). The data were calculated using Bio-Plex Manager software (Version 5.0; Bio-Rad Laboratories).

4.10. Western Blot Analysis. The A549 cell monolayers in six-well plates were incubated with PR8 at a MOI of 1 for 2 $\mathrm{h}$ at $37^{\circ} \mathrm{C}$. The virus inoculum was then removed and replaced with DMEM medium containing twofold serially diluted DDEA. At 24 hpi., cells were lysed on ice for 10 min with radio immunoprecipitation assay lysis buffer (Beyotime Institute of Biotechnology) containing a phosphatase inhibitor cocktail (Sigma). Protein concentration was measured using a bicinchoninic acid protein assay kit (Invitrogen Life Technologies). Western blots were performed on PVDF membranes as described, ${ }^{51}$ using primary antibodies (CST Biological Reagents) to identify TLR-3, RIG-I, IRF-3, $p$-IRF3, p65, p-p65, ERK, $p$-ERK, Akt, $p$-Akt, p38, p-p38, STAT2, $p$ STAT2, and GAPDH at a dilution following the manufacturer's protocol. After incubation with primary antibodies, horseradish peroxidase-conjugated secondary antibody (CST Biological Reagents) was added to PVDF membranes for 60 min at room temperature (RT). The target proteins were visualized using a western lighting chemiluminescence system (Thermo Fisher Scientific) and quantified by ImageJ software (NIH, Bethesda).

4.11. Statistics. Statistical differences between groups were compared using one-way analysis of variance in GraphPad Prism 8.0 software. Values of $p<0.05$ were considered as significant.

\section{ASSOCIATED CONTENT}

\section{Supporting Information}

The Supporting Information is available free of charge at https://pubs.acs.org/doi/10.1021/acsomega.0c05264.

Additional data associated with isolation and synthesis of DDEA and the primer sequences used in this study (PDF)

\section{AUTHOR INFORMATION}

\section{Corresponding Authors}

Guo-Yuan Zhu - State Key Laboratory of Quality Research in Chinese Medicine, Macau University of Science and Technology, Macau (SAR) 519020, China; 이이.org/ 0000-0002-4355-894X; Email: zhjiang@must.edu.mo

Zhi-Hong Jiang - State Key Laboratory of Quality Research in Chinese Medicine, Macau University of Science and Technology, Macau (SAR) 519020, China; 이이.org/ 0000-0002-7956-2481; Email: gyzhu@must.edu.mo

\section{Authors}

Run-Feng Li - State Key Laboratory of Quality Research in Chinese Medicine, Macau University of Science and Technology, Macau (SAR) 519020, China; 이이.org/ 0000-0002-8575-616X

Xiao-Bo Zhou - State Key Laboratory of Quality Research in Chinese Medicine, Macau University of Science and Technology, Macau (SAR) 519020, China

Hong-Xia Zhou - Dongguan People's Hospital, Dongguan 523000, China

Zi-Feng Yang - State Key Laboratory of Respiratory Disease, National Clinical Research Center for Respiratory Disease, Guangzhou Institute of Respiratory Health, the First Affiliated Hospital of Guangzhou Medical University, Guangzhou Medical University, Guangzhou 510120, China; State Key Laboratory of Quality Research in Chinese Medicine, Macau University of Science and Technology, Macau (SAR) 519020, China; KingMed Virology Diagnostic \& Translational Center, Guangzhou 510000, China; Guangdong-Hong Kong-Macao Joint Laboratory of Infectious Respiratory Disease, Guangzhou 510000, China

Hai-Ming Jiang - State Key Laboratory of Respiratory Disease, National Clinical Research Center for Respiratory Disease, Guangzhou Institute of Respiratory Health, the First Affiliated Hospital of Guangzhou Medical University, Guangzhou Medical University, Guangzhou 510120, China

Xiao Wu - State Key Laboratory of Respiratory Disease, National Clinical Research Center for Respiratory Disease, Guangzhou Institute of Respiratory Health, the First Affiliated Hospital of Guangzhou Medical University, Guangzhou Medical University, Guangzhou 510120, China

Wen-Jia Li - Dongguan HEC Cordyceps R\&D Co.,Ltd, Dongguan 523850, China

Jian-Jian Qiu - Dongguan HEC Cordyceps R\&D Co.,Ltd, Dongguan 523850, China

Jia-Ning Mi - State Key Laboratory of Quality Research in Chinese Medicine, Macau University of Science and Technology, Macau (SAR) 519020, China

Ming Chen - State Key Laboratory of Quality Research in Chinese Medicine, Macau University of Science and Technology, Macau (SAR) 519020, China

Nan-Shan Zhong - State Key Laboratory of Respiratory Disease, National Clinical Research Center for Respiratory 
Disease, Guangzhou Institute of Respiratory Health, the First Affiliated Hospital of Guangzhou Medical University, Guangzhou Medical University, Guangzhou 510120, China; State Key Laboratory of Quality Research in Chinese Medicine, Macau University of Science and Technology, Macau (SAR) 519020, China

Complete contact information is available at:

https://pubs.acs.org/10.1021/acsomega.0c05264

\section{Author Contributions}

${ }^{\mathbb{T}}$ R.-F. L., X.-B. Z., and H.-X. Z. made equal contributions to this study.

\section{Notes}

The authors declare no competing financial interest.

\section{ACKNOWLEDGMENTS}

This work was supported by the National Natural Science Foundation of China (grant no. 81872765), the Science and Technology Development Fund of Macao Special Administrative Region (grant no. 125/2017/A3), and the Guangdong-Hong Kong-Macao Joint Laboratory of Infectious Respiratory Disease (grant no. 2019B121205010).

\section{REFERENCES}

(1) Paget, J.; Spreeuwenberg, P.; Charu, V.; Taylor, R. J.; Iuliano, A. D.; Bresee, J.; Simonsen, L.; Viboud, C. Global mortality associated with seasonal influenza epidemics: New burden estimates and predictors from the GLaMOR Project. J. Glob. Health 2019, 9, 020421.

(2) Simon, P. F.; de La Vega, M.-A.; Paradis, É.; Mendoza, E.; Coombs, K. M.; Kobasa, D.; Beauchemin, C. A. A. Avian influenza viruses that cause highly virulent infections in humans exhibit distinct replicative properties in contrast to human H1N1 viruses. Sci. Rep. 2016, 6, 24154.

(3) van den Brand, J. M. A.; Stittelaar, K. J.; van Amerongen, G.; Rimmelzwaan, G. F.; Simon, J.; de Wit, E.; Munster, V.; Bestebroer, T.; Fouchier, R. A. M.; Kuiken, T.; Osterhaus, A. D. M. E. Severity of pneumonia due to new H1N1 influenza virus in ferrets is intermediate between that due to seasonal H1N1 virus and highly pathogenic avian influenza H5N1 virus. J. Infect. Dis. 2010, 201, 993-999.

(4) Centers for Disease Control and Prevention. Antiviral Drugs for Seasonal Influenza: Additional Links and Resources; https://www.cdc. gov/flu/professionals/antivirals. 2020.

(5) Salihefendic, N.; Zildzic, M.; Ahmetagic, S. Acute respiratory distress syndrome (ARDS) from endemic influenza A/H1N1: Prehospital management. Med. Arh. 2015, 69, 62-63.

(6) Thorlund, K.; Awad, T.; Boivin, G.; Thabane, L. Systematic review of influenza resistance to the neuraminidase inhibitors. $B M C$ Infect. Dis. 2011, 11, 134.

(7) Hurt, A. C.; Leang, S. K.; Tiedemann, K.; Butler, J.; Mechinaud, F.; Kelso, A.; Downie, P.; Barr, I. G. Progressive emergence of an oseltamivir-resistant $\mathrm{A}(\mathrm{H} 3 \mathrm{~N} 2)$ virus over two courses of oseltamivir treatment in an immunocompromised paediatric patient. Influenza Other Respir. Viruses 2013, 7, 904-908.

(8) Newton, A. H.; Cardani, A.; Braciale, T. J. The host immune response in respiratory virus infection: balancing virus clearance and immunopathology. Semin. Immunopathol. 2016, 38, 471-482.

(9) Teijaro, J. R.; Walsh, K. B.; Cahalan, S.; Fremgen, D. M.; Roberts, E.; Scott, F.; Martinborough, E.; Peach, R.; Oldstone, M. B. A.; Rosen, H. Endothelial cells are central orchestrators of cytokine amplification during influenza virus infection. Cell 2011, 146, 980991.

(10) La Gruta, N. L.; Kedzierska, K.; Stambas, J.; Doherty, P. C. A question of self-preservation: immunopathology in influenza virus infection. Immunol. Cell Biol. 2007, 85, 85-92.
(11) Elbahesh, H.; Gerlach, T.; Saletti, G.; Rimmelzwaan, G. F. Response modifiers: Tweaking the immune response against influenza A virus. Front. Immunol. 2019, 10, 809.

(12) Biondo, C.; Lentini, G.; Beninati, C.; Teti, G. The dual role of innate immunity during influenza. Biomed. J. 2019, 42, 8-18.

(13) Guleria, R.; Kumar, J.; Mohan, A.; Wig, N. Influenza A: From highly pathogenic H5N1 to pandemic $2009 \mathrm{H} 1 \mathrm{~N} 1$. Epidemiology and clinical features. Indian J. Microbiol. 2009, 49, 315-319.

(14) Centers for Disease Control and Prevention. About Flu; https://www.cdc.gov/flu/about 2019.

(15) Itoh, Y.; Shinya, K.; Kiso, M.; Watanabe, T.; Sakoda, Y.; Hatta, M.; Muramoto, Y.; Tamura, D.; Sakai-Tagawa, Y.; Noda, T.; Sakabe, S.; Imai, M.; Hatta, Y.; Watanabe, S.; Li, C.; Yamada, S.; Fujii, K.; Murakami, S.; Imai, H.; Kakugawa, S.; Ito, M.; Takano, R.; IwatsukiHorimoto, K.; Shimojima, M.; Horimoto, T.; Goto, H.; Takahashi, K.; Makino, A.; Ishigaki, H.; Nakayama, M.; Okamatsu, M.; Takahashi, K.; Warshauer, D.; Shult, P. A.; Saito, R.; Suzuki, H.; Furuta, Y.; Yamashita, M.; Mitamura, K.; Nakano, K.; Nakamura, M.; BrockmanSchneider, R.; Mitamura, H.; Yamazaki, M.; Sugaya, N.; Suresh, M.; Ozawa, M.; Neumann, G.; Gern, J.; Kida, H.; Ogasawara, K.; Kawaoka, Y. In vitro and in vivo characterization of new swine-origin H1N1 influenza viruses. Nature 2009, 460, 1021-1025.

(16) Gao, R.; Bhatnagar, J.; Blau, D. M.; Greer, P.; Rollin, D. C.; Denison, A. M.; Deleon-Carnes, M.; Shieh, W.-J.; Sambhara, S.; Tumpey, T. M.; Patel, M.; Liu, L.; Paddock, C.; Drew, C.; Shu, Y.; Katz, J. M.; Zaki, S. R. Cytokine and chemokine profiles in lung tissues from fatal cases of 2009 pandemic influenza A (H1N1): role of the host immune response in pathogenesis. Am. J. Pathol. 2013, 183, $1258-1268$

(17) Ng, T. B.; Wang, H. X. Pharmacological actions of Cordyceps, a prized folk medicine. J. Pharm. Pharmacol. 2005, 57, 1509-1519.

(18) Paterson, R. R. M. Cordyceps: a traditional Chinese medicine and another fungal therapeutic biofactory? Phytochemistry 2008, 69, 1469-1495.

(19) Zhou, Y.; Wang, M.; Zhang, H.; Huang, Z.; Ma, J. Comparative study of the composition of cultivated, naturally grown Cordyceps sinensis, and stiff worms across different sampling years. PLoS One 2019, 14, No. e0225750.

(20) Zhang, X.; Liu, Q.; Zhou, W.; Li, P.; Alolga, R. N.; Qi, L.-W.; Yin, X. A comparative proteomic characterization and nutritional assessment of naturally- and artificially-cultivated Cordyceps sinensis. J. Proteomics 2018, 181, 24-35.

(21) Liu, Y.; Wang, J.; Wang, W.; Zhang, H.; Zhang, X.; Han, C. The chemical constituents and pharmacological actions of cordyceps sinensis. Evid.-Based Complementary Altern. Med 2015, 2015, 575063.

(22) Zhao, J.; Xie, J.; Wang, L. Y.; Li, S. P. Advanced development in chemical analysis of Cordyceps. J. Pharm. Biomed. Anal. 2014, 87, 271-289.

(23) Mi, J.-N.; Wang, J.-R.; Jiang, Z.-H. Quantitative profiling of sphingolipids in wild Cordyceps and its mycelia by using UHPLCMS. Sci. Rep. 2016, 6, 20870.

(24) Mi, J.-N.; Han, Y.; Xu, Y.; Kou, J.; Wang, J.-R.; Jiang, Z.-H. New immunosuppressive sphingoid base and ceramide analogues in wild Cordyceps. Sci. Rep. 2016, 6, 38641.

(25) Mi, J.; Han, Y.; Xu, Y.; Kou, J.; Li, W.-J.; Wang, J.-R.; Jiang, Z.$H$. Deep profiling of immunosuppressive glycosphingolipids and sphingomyelins in wild Cordyceps. J. Agric. Food Chem. 2018, 66, 8991-8998.

(26) Still, W. C.; Gennari, C. Direct synthesis of Z-unsaturated esters. A useful modification of the horner-emmons olefination. Tetrahedron Lett. 1983, 24, 4405-4408.

(27) Shin, D.; Rew, Y.; Boger, D. L. Total synthesis and structure of the ramoplanin A1 and A3 aglycons: two minor components of the ramoplanin complex. Proc. Natl. Acad. Sci. U.S.A. 2004, 101, 1197711979.

(28) Guo, L.-X.; Xu, X.-M.; Hong, Y.-H.; Li, Y.; Wang, J.-H. Stable Carbon Isotope Composition of the lipids in natural Ophiocordyceps sinensis from major habitats in China and its substitutes. Molecules 2017, 22, 1567. 
(29) Guo, L.-X.; Xu, X.-M.; Liang, F.-R.; Yuan, J.-P.; Peng, J.; Wu, C.-F.; Wang, J.-H. Morphological observations and fatty acid composition of indoor-cultivated Cordyceps sinensis at a high-altitude laboratory on Sejila Mountain, Tibet. PLoS One 2015, 10, No. e0126095.

(30) Yang, F. Q.; Feng, K.; Zhao, J.; Li, S. P. Analysis of sterols and fatty acids in natural and cultured Cordyceps by one-step derivatization followed with gas chromatography-mass spectrometry. J. Pharm. Biomed. Anal. 2009, 49, 1172-1178.

(31) Lee, H. H.; Park, H.; Sung, G.-H.; Lee, K.; Lee, T.; Lee, I.; Park, M.-s.; Jung, Y. W.; Shin, Y. S.; Kang, H.; Cho, H. Anti-influenza effect of Cordyceps militaris through immunomodulation in a DBA/2 mouse model. J. Microbiol. 2014, 52, 696-701.

(32) Ohta, Y.; Lee, J.-B.; Hayashi, K.; Fujita, A.; Park, D. K.; Hayashi, T. In vivo anti-influenza virus activity of an immunomodulatory acidic polysaccharide isolated from Cordyceps militaris grown on germinated soybeans. J. Agric. Food Chem. 2007, 55, 1019410199.

(33) de Toledo-Piza, A. R.; de Oliveira, M. I.; Negri, G.; Mendonça, R. Z.; Figueiredo, C. A. Polyunsaturated fatty acids from Phyllocaulis boraceiensis mucus block the replication of influenza virus. Arch. Microbiol. 2018, 200, 961-970.

(34) Pizzorno, A.; Padey, B.; Terrier, O.; Rosa-Calatrava, M. Drug repurposing approaches for the treatment of influenza viral infection: Reviving old drugs to fight against a long-lived enemy. Front. Immunol. 2019, 10, 531 .

(35) Yip, T.-F.; Selim, A. S. M.; Lian, I.; Lee, S. M.-Y. Advancements in host-based interventions for influenza treatment. Front. Immunol. 2018, 9, 1547.

(36) Meineke, R.; Rimmelzwaan, G.; Elbahesh, H. Influenza virus infections and cellular kinases. Viruses 2019, 11, 171.

(37) Hirata, N.; Suizu, F.; Matsuda-Lennikov, M.; Edamura, T.; Bala, J.; Noguchi, M. Inhibition of Akt kinase activity suppresses entry and replication of influenza virus. Biochem. Biophys. Res. Commun. 2014, 450, 891-898.

(38) Chen, X.; Liu, S.; Goraya, M. U.; Maarouf, M.; Huang, S.; Chen, J. L. Host immune response to influenza A virus infection. Front. Immunol. 2018, 9, 320.

(39) Iwasaki, A.; Pillai, P. S. Innate immunity to influenza virus infection. Nat. Rev. Immunol. 2014, 14, 315-328.

(40) Lee, N.; Chan, P. K.; Wong, C. K.; Wong, K.-T.; Choi, K.-W.; Joynt, G. M.; Lam, P.; Chan, M. C.; Wong, B. C.; Lui, G. C.; Sin, W. W.; Wong, R. Y.; Lam, W.-Y.; Yeung, A. C.; Leung, T.-F.; So, H.-Y.; Yu, A. W.; Sung, J. J.; Hui, D. S. Viral clearance and inflammatory response patterns in adults hospitalized for pandemic 2009 influenza A(H1N1) virus pneumonia. Antivir. Ther. 2011, 16, 237-247.

(41) de Jong, M. D.; Simmons, C. P.; Thanh, T. T.; Hien, V. M.; Smith, G. J. D.; Chau, T. N. B.; Hoang, D. M.; Van Vinh Chau, N.; Khanh, T. H.; Dong, V. C.; Qui, P. T.; Van Cam, B.; Ha, D. Q.; Guan, Y.; Peiris, J. S. M.; Chinh, N. T.; Hien, T. T.; Farrar, J. Fatal outcome of human influenza A (H5N1) is associated with high viral load and hypercytokinemia. Nat. Med. 2006, 12, 1203-1207.

(42) Perrin-Cocon, L.; Aublin-Gex, A.; Sestito, S. E.; Shirey, K. A.; Patel, M. C.; Andre, P.; Blanco, J. C.; Vogel, S. N.; Peri, F.; Lotteau, V. TLR4 antagonist FP7 inhibits LPS-induced cytokine production and glycolytic reprogramming in dendritic cells, and protects mice from lethal influenza infection. Sci. Rep. 2017, 7, 40791.

(43) Shirey, K. A.; Lai, W.; Scott, A. J.; Lipsky, M.; Mistry, P.; Pletneva, L. M.; Karp, C. L.; McAlees, J.; Gioannini, T. L.; Weiss, J.; Chen, W. H.; Ernst, R. K.; Rossignol, D. P.; Gusovsky, F.; Blanco, J. C. G.; Vogel, S. N. The TLR4 antagonist Eritoran protects mice from lethal influenza infection. Nature 2013, 497, 498-502.

(44) Li, Z.; Li, L.; Zhou, H.; Zeng, L.; Chen, T.; Chen, Q.; Zhou, B.; Wang, Y.; Chen, Q.; Hu, P.; Yang, Z. Radix isatidis polysaccharides inhibit influenza A virus and influenza A virus-induced inflammation via suppression of host TLR3 signaling in vitro. Molecules 2017, 22, 116.

(45) Hui, K. P. Y.; Lee, S. M. Y.; Cheung, C.-y.; Mao, H.; Lai, A. K. W.; Chan, R. W. Y.; Chan, M. C. W.; Tu, W.; Guan, Y.; Lau, Y.-L.;
Peiris, J. S. M. H5N1 influenza virus-induced mediators upregulate RIG-I in uninfected cells by paracrine effects contributing to amplified cytokine cascades. J. Infect. Dis. 2011, 204, 1866-1878.

(46) Wu, W.; Zhang, W.; Duggan, E. S.; Booth, J. L.; Zou, M.-H.; Metcalf, J. P. RIG-I and TLR3 are both required for maximum interferon induction by influenza virus in human lung alveolar epithelial cells. Virology 2015, 482, 181-188.

(47) Stanifer, M. L.; Pervolaraki, K.; Boulant, S. Differential regulation of type I and type III interferon signaling. Int. J. Mol. Sci. 2019, 20, 1445

(48) Hervas-Stubbs, S.; Perez-Gracia, J. L.; Rouzaut, A.; Sanmamed, M. F.; Le Bon, A.; Melero, I. Direct effects of type I interferons on cells of the immune system. Clin. Cancer Res. 2011, 17, 2619-2627.

(49) Davidson, S.; McCabe, T. M.; Crotta, S.; Gad, H. H.; Hessel, E. M.; Beinke, S.; Hartmann, R.; Wack, A. IFN $\lambda$ is a potent antiinfluenza therapeutic without the inflammatory side effects of IFN $\alpha$ treatment. EMBO Mol. Med. 2016, 8, 1099-1112.

(50) Zhou, B.; Liang, X.; Feng, Q.; Li, J.; Pan, X.; Xie, P.; Jiang, Z.; Yang, Z. Ergosterol peroxide suppresses influenza A virus-induced pro-inflammatory response and apoptosis by blocking RIG-I signaling. Eur. J. Pharmacol. 2019, 860, 172543.

(51) Wang, Y.; Li, J.; Yan, W.; Chen, Q.; Jiang, Z.; Zhang, R.; Pan, $\mathrm{X}$.; Wang, X. An active component containing pterodontic acid and pterodondiol isolated from Laggera pterodonta inhibits influenza $A$ virus infection through the TLR7/MyD88/TRAF6/NF- $\kappa$ B signaling pathway. Mol. Med. Rep. 2018, 18, 523-531. 